\title{
Aliran Rasionalisme dan Empirisme dalam Kerangka Ilmu Pengetahuan
}

\author{
Susanti Vera', R. Yuli A. Hambali2 \\ 1 Program Studi Ilmu Al-Qur'an dan Tafsir \\ Pascasarjana UIN Sunan Gunung Djati Bandung \\ ${ }^{2}$ Jurusan Akidah Filsafat Islam, Fakultas Ushuluddin, \\ UIN Sunan Gunung Djati Bandung \\ susantivera96@gmail.com
}

\begin{abstract}
This study aims to discuss the flow of rationalism and empiricism within the framework of science. The research method used is a qualitative type through literature study. The result and discussion of this research is that there are fundamental differences between science and knowledge at the level of philosophy of science. Science and knowledge are produced by human absorption of everything that is guided by curiosity (curiosity) which is human nature. The knowledge that is owned is then tested for accuracy by fulfilling three basic aspects of science, namely ontology (the object of knowledge), epistemology (how to obtain knowledge), and axiology (the use value of science). This study concludes that epistemologically, there are two understandings about the source of knowledge, namely, rationalism and empiricism. Rationalism believes that reason is the main source of knowledge and emepiriism believes that only sensory experience brings true knowledge. Both of them have a big role in the development of science to reach a critical human civilization and are able to survive as a superior identity in this universe.
\end{abstract}

Keywords: Empiricism; Knowledge; Rationalism; Science.

\begin{abstract}
Abstrak
Penelitian ini bertujuan membahas aliran rasionalisme dan empirisme dalam kerangka ilmu pengetahuan. Metode penelitian yang digunakan ialah jenis kualitatif melalui studi pustaka. Hasil dan pembahasan penelitian ini ialah terdapat perbedaan yang mendasar antara ilmu dan pengetahuan dalam tataran filsafat ilmu. Ilmu dan pengetahuan dihasilkan oleh daya serap manusia terhadap segala sesuatu yang
\end{abstract}


dipandu oleh curiosity (rasa ingin tahu) yang menjadi fitrah manusia. Ilmu pengetahuan yang dimilki kemudian diuji keakuratannya dengan memenuhi tiga aspek dasar ilmu yaitu ontologi (objek pengetahuan), epistemologi (cara memperoleh pengetahuan), dan aksiologi (nilai guna ilmu pengetahuan). Penelitian ini menyimpulkan bahwa secara epistemologis terdapat dua paham mengenai sumber ilmu pengetahuan yaitu, rasionalisme dan empirisme. Rasionalisme meyakini bahwa rasio adalah sumber utama pengetahuan dan emepirisme meyakini hanya pengalaman inderawi yang membawa pengetahuan yang benar. Keduanya memiliki peran yang besar dalam pemkembangan ilmu hingga mencapai peradaban manusia yang kritis serta mampu bertahan sebagai identitas unggul di alam semesta ini.

Kata kunci: Empirisme; Ilmu; Pengetahuan; Rasionalisme.

\section{Pendahuluan}

Manusia adalah makhluk yang diberikan keistimewaan serta bekal hidup yang luar biasa oleh Allah SWT. Manusia dibekali akal fikiran dan hati yang berfungsi mengelola sistem kehidupan (Azmi, 2018). Ibnu 'Arabi menggambarkan keunggulan manusia dengan mengatakan "tidak ada makhluk Allah yang lebih bagus daripada manusia, karena manusia memiliki daya hidup seperti mengetahui, berkehendak, berfikir dan memutuskan" (Al-Faruq, 1984). Namun, kelebihan tersebut tidak untuk menjadikan manusia diam dan tidak mengasah kemampuan untuk mengamati fenomena alam nyata. Manusia dilengkapi dengan sifat kodrati yaitu mempunyai rasa ingin tahu. Rasa ingin tahu tersebut tidak terbatas pada apa yang ada dalam dirinya sendiri tetapi juga lingkungan dan kehidupan (Indrioko, 2020). Rasa ingin tahu membawa manusia pada potensi pengembangan diri secara maksimal melalui hal-hal yang dirasakan, dilihat, dan didengar, semua hal ini merupakan sumber dalam bidang pengetahuan. Sejauh ini ada dua aliran yang menjadi sumber dasar ilmu pengetahuan yaitu, aliran rasionalisme yang bersumber dari akal dan aliran empirisme yang bersumber dari pengamatan. Keduanya memberikan kerangka masing-masing dalam mencapai tanggung jawab kebenaran pengetahuan, namun tidak semua pengetahuan baik untuk diamalkan dan diajarkan. Oleh karena itu, struktur sumber ilmu pengetahuan dibutuhkan sehingga ilmu menjadi sebuah sistem yang utuh dan teruji kebenarannya (interconnected). 
Beberapa penelitian terdahulu telah membahas mengenai pengertian ilmu dan pengetahuan dari berbagai sudut pandang. Di antaranya adalah Sri Rahayu wilujeng (2014), berjudul Ilmu Dalam Perspektif Filsafat (Suatu Upaya Mengembalikan Ilmu Pada Hakikatnya), Jurnal Humanika. Penelitian ini merupakan jenis kualitatif dengan beberapa langkah metodis yaitu: deskripsi, interpretasi, analisa-sintesa dan idealisasi. Penelitian ini menggunakan landasan filsafat ilmu. Penelitian ini menyimpulkan bahwa semua bangunan ilmu berada pada tiga landasan filosofis yaitu: landasan ontologis, landasan epistemologis dan landasan etis (Wilujeng, 2014). Komariah (2017), berjudul Struktur Ilmu Pengetahuan, Jurnal Genologi PAI. Penelitian ini adalah jenis kualitatif melalui studi pustaka dengan menggunakan analisis struktur ilmu dan pengetahuan dalam filsafat ilmu. Penelitian ini menggunakan teori objek dan subjek ilmu. Penelitian ini menyimpulkan bahwa ilmu ialah rangkaian aktivitas manusia yang kognitif dan rasional dengan berbagai macam metode berupa tata langkah serta aneka prosedur sehingga mencapai kumpulan pengetahuan yang sistematis dari pemahaman hingga penerapan (Komariah, 2017). M. Ied Al Munir (2004), berjudul Tinjauan Terhadap Metode Empirisme Dan Rasionalisme, Jurnal Filsafat. Penelitian ini merupakan jenis kualitatif dengan studi pustaka dengan analisis metode ilmiah. Penelitian ini menggunakan teori filsafat modern. Penelitian ini menyimpulkan bahwa rasionalisme dan empirisme sebagai metode untuk mendapatkan pengetahuan, masing-masing memilki kelemahan yang mendasar. Dengan demikian perlu mengawinkan kedua metode tersebut untuk menutupi kekurangan masing-masing. Perkawinan antara rasionalisme dan empirisme dapat digambarkan dalam metode ilmiah dengan langkah sebagai berikut, yaitu perumusan masalah, kerangka berfikir, hipotesis, uji hipotesis, dan kesimpulan (Munir, 2004).

Sejumlah penelitian terdahulu berharga bagi penyusunan kerangka berpikir penelitian ini. Mengenal ilmu pengetahuan merupakan kegiatan pokok manusia yang selalu mengalami perkembangan dan kemajuan (Karim, 2014). Ilmu pengetahuan merupakan hasil dari proses berfikir disertai pengamatan dari seluruh indera manusia hingga sampai pada kesimpulan yang disebut pengetahuan (Suriasumantri, Ilmu dalam Perspektif, 2009). Manusia memiliki curiosity (perasaan ingin tahu) disertai rasa ragu dalam mengenal sesuatu, hal ini sudah menjadi karakter dan sifat yang ada dalam diri manusia (Bayu Purbo Asmoro, 2019). Curiosity akan membawa manusia pada seluruh pengetahuan, yaitu berupa ilmu yang bersifat kealaman yang bisa diamati (empiric) dan ilmu yang non-empirik atau ilmu metafisik yang diakui keberadannya sebagai ilmu (Khotimah, 2014). Ilmu dan pengetahuan memiliki definisi yang berbeda, pengetahuan ialah sekumpulan yang diketahui manusia secara sadar meliputi mitos, fakta, dan segala fenomena dalam alam manusia. Sementara ilmu ialah sekumpulan pengetahuan berdasarkan teori-teori yang disepakati dan secara sistematik, diuji dengan seperangkat metode yang diakui dalam bidang ilmu tertentu (Dafrita, 2015). Ilmu pengetahuan sebagai produk proses berfikir memiliki tujuan mencari kebenaran. Dalam hal ini filsafat 
ilmu menstrukturkan kerangka ilmu pengetahuan, serta mengoptimalkan pemikiran yang rasional (kritis, logis, dan sistematis) serta bersifat obyektif, mendalam dan menyeluruh dalam menyelami ilmu pengetahuan (Wahana, 2016). Pada hakikatnya aktivitas ilmu pengetahuan digerakkan pada tiga masalah pokok yaitu objek pengetahuan (Ontologi), cara memperoleh pengetahuan (Epistemologi), dan nilai kegunaan pengetahuan (Aksiologi) (Bahrum, 2013). Dalam menemukan kebenaran ilmu pengetahuan, manusia menggunakan dua cara dalam memperolehnya yaitu, pertama melalui rasio, kedua melalui pengalaman. Paham yang pertama disebut aliran rasionalisme sedangkan paham yang kedua disebut dengan empirisme (Bahktiar, 2004). Rasionalisme merupakan sebuah paham yang menekankan pikiran atau daya nalar sebagai sumber utama menemukan pengetahuan serta pemegang otoritas penentu kebenaran (Lubis, 2011). Adapun empirisme ialah paham yang mengatakan bahwa pengalaman indrawi adalah satu-satunya sumber serta penjamin kepastian kebenaran (Rusmini, 2014).

Berdasarkan paparan di atas, penelitian ini berusaha menyusun formula penelitian, yaitu rumusan, pertanyaan dan tujuan penelitian (Darmalaksana, 2020). Rumusan masalah penelitian ini terdapat aliran rasionalisme dan empirisme dalam kerangka ilmu pengetahuan. Pertanyaan utama penelitian ini ialah bagaimana aliran rasionalisme dan empirisme dalam kerangka ilmu pengetahuan. Penelitian ini bertujuan membahas aliran rasionalisme dan empirisme dalam kerangka ilmu pengetahuan.

\section{Metode Penelitian}

Penelitian ini merupakan jenis kualitatif yaitu melakukan penghimpunan data dari sumber kepustakaan (Darmalaksana, 2020). Sumber kepustakaan yang digunakan ialah sumber primer dan sekunder. Sumber primer meliputi buku-buku filsafat ilmu. Sumber sekunder meliputi artikel-artikel jurnal terkait pokok bahasan mengenai pemetaan kerangka sumber ilmu pengetahuan. Terhadap data yang telah terhimpun dilakukan analisis hasil temuan untuk menarik sebuah kesimpulan (Darmalaksana, 2020). Adapun pendekatan yang digunakan dalam menemukan hasil ialah prosedur sistematis kerangka ilmu pengetahuan.

\section{Hasil dan Pembahasan}

Hasil dan pembahasan penelitian di bawah ini:

\section{Manusia dan Rasa Ingin Tahu (Curiosity)}

Manusia berbeda dengan makhluk lainnya yang hidup di bumi dan alam materi yang sama. Manusia memilki sikap ilmiah dalam memperoleh pengetahuan. Setiap kesempatan mendapat hal-hal yang baru dan mengalami kejadian-kejadian, dan gejala-gejala yang bersentuhan dengan kehidupan dalam bermasyarakat, manusia senantiasa ingin segera 
mengetahuinya. Ini merupakan dorongan akal manusia yang terus peka terhadap sesuatu yang terjadi di sekelilingnya. Sering bertanya apa ini dan itu, pertanyaan tersebut ialah wujud dari keingintahuan manusia terhadap segala hal yang dialami secara langsung maupun tidak. Hal ini membuka cakrawala pengetahuan baru dan inovanif, sungguh keingintahuan manusia merupakan sebuah rahmat yang dahsyat (Kirom, 2011).

Perbedaan manusia dengan makhluk ciptaan Tuhan lainnya ditandai oleh kemampuan manusia memiliki pengetahuan. Manusia sering merumuskan hipotesis-hipotesis atau teori tentang sifat dasar suatu hal dan mengujinya dengan cara pengamatan dan percobaan untuk mendapatkan hasil yang benar (Banasuru, 2013). Hal ini bisa disebut juga dengan pengandaian, manusia sering sekali berandai-andai, andai seperti itu dan seperti ini pasti hasilnya seperti itu dan seperti ini. Pengandaian mengantarkan manusia kepada serba kemungkinan dalam kehidupan. Pengandaian tersebut jarang dibicarakan secara mendalam dan memberikan pertanggung jawaban yang memadai. Semakin seringnya terjadi pengandaian-pengandaian yang sama dalam karakter yang sama pula mengantar pengandaian menjadi pengalaman. Pengalaman yang sama sering mengantarkan manusia menjadikannya sebuah pengetahuan.

Hasrat keingintahuan dijadikan prinsip dalam naluri paling dasar bagi manusia, yakni naluri mencari kebenaran atau pengetahuan yang tak terhingga dan tak terpuaskan (Yazdi, 1999). Salah satu tokoh filsafat yaitu Aristoteles mengatakan bahwa cikal-bakal pengetahuan bermula dari rasa kagum dan heran, menggumamkan bahwa rasa heran merupakan nenek moyang (arkhe) dari "hasrat akan kebijaksanaan" philosophia (Gallagher, 2010). Dengan demikian rasa ingin tahu manusia akan kebenaran sudah menjadi kodrat dan simbol akal yang murni sejak lahir.

Dalam tataran filsafat, sebuah pengetahuan tidak dapat diterima begitu saja. Karena setiap persoalan yang telah menjadi pendapat umum harus dapat diuji dan memiliki dasar argumentasi yang diterima secara rasional. Tidak cukup bagi filsafat untuk mengandaikan begitu saja bahwa manusia dapat memiliki pengetahuan. Filsafat perlu mempertanyakan kodrat dan lingkup pengetahuan dasar untuk sampai pada persoalan yang dasar sekalipun, sekurang-kurangnya manusia harus mengetahui hakikat dan pertanggungjawaban pengetahuan yang ia miliki (Banasuru, 2013).

\section{Definisi Ilmu dan Pengetahuan}

Ilmu dan pengetahuan berbeda dalam pandangan filsafat. Filsafat di sini bisa dipahami sebagai filsafat pengetahuan yang secara spesifik mengkaji hakikat ilmu pengetahuan, ilmu ialah cabang dari pengetahuan dan filsafat ilmu ialah usaha akal manusia secara taat mengkaji asas pengetahuan menuju penemuan yang benar (Baktiar, 2012). Ilmu bertumpu pada analisis terhadap data pengamatan dan percobaan secara impersonal, 
berdasarkan hasil-hasil observasi dan eksperimen dengan analisis objektif. Pengetahuan adalah semua fikiran dan pemahaman tentang alam yang diperoleh tidak melalui siklus berfikir metode ilmiah yaitu logico-hipoteticoverifikatif. Pengetahuan yang sifatnya dogmatis, banyak mengandung spekulasi dan tidak berpijak pada kenyataan empiris. Contoh ramalan ilmu ialah ketika ramalan cuaca menurut ahli meteorologi, kemudian contoh ramalan diluar keilmuan yaitu ramalan jodoh, nasib, atau ramalan kupon berhadiah itu semua meruapakan keilmuan yang tidak dapat dipertanggungjawabkan (Suriasumantri, Filsafat Ilmu Sebuah Pengantar Populer, 2009).

Pengetahuan yang bersifat dogmatis dapat digambarkan mempunyai ciri khusus, yaitu metode transfer pengetahuan. Pengetahuan yang ditransfer berupa sesuatu yang dipercaya dari leluhur, atau mitos-mitos yang berkembang di kalangan masyarakat. Pengetahuan seperti ini biasanya tidak bersifat dialektis dan cukup menjadi wawasan setiap individu (Wijaya T. S., 2017). Hal ini menjadi perbedaan yang mendasar antara pengetahuan dan ilmu, ilmu mempunyai disiplin yang sistematis dan dapat dipertanggungjawabkan keberadannya. Ilmu tidak lepas dari berbagai perasangka dan keraguan sehingga ilmu memiliki berbagai kemungkinan pemahaman dan terbuka untuk dialektika serta penelitian secara cermat (Makbul, 2020). Dengan demikian semua ilmu pasti pengatahuan dan tidak semua pengetahuan adalah ilmu, gambar 1 merupakan bagan sederhana mengenai struktur pengetahuan.

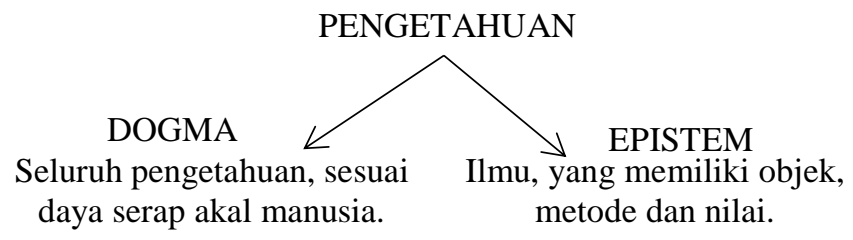

Gambar 1 struktur pengetahuan

Ilmu dan pengetahuan secara etimologi, ilmu dalam bahasa Inggris disebut sebagai science, yaitu kata serapan dari bahasa Latin scientia, yang merupakan turunan dari kata scire, kata ini mempunyai arti belajar (to learn) juga mengetahui (to know). Ilmu juga berasal dari bahasa Arab yaitu 'ilm yang artinya mengetahui. Sementara pengetahuan dalam bahasa Inggris disebut sebagai knowledge yang mempunyai arti; (1) keadaan atau kondisi menyadari sesuatu, (2) kenyataan mengetahui sesuatu yang diperoleh melalui pengalaman atau asosiasi, (3) sejumlah pengetahuan, susunan kebenaran informasi, dan (4) kenyataan atau kondisi memiliki informasi yang sedang dipelajari (Daud, 2015).

Ilmu pengetahuan secara terminologi terdapat beberapa pendapat para ahli, di antaranya: Imam al-Ghazali, yang menggambarkan ilmu 
sebagai pengetahuan tentang sesuatu sebagimana adanya (ma'rifat al-shay' 'ala mahuwa bihi), definisi ma'rifah menyiratkan fakta bahwa ilmu merupakan jenis penemuan makna pada suatu objek (Marpaung, 2011). Kemudian menurut tokoh lain yaitu Ralph Ross menulis: "Science is empirical, rational, general and cumulative; and it is all four at once" (ilmu ialah suatu yang empiris, rasional, umum dan serta berkumpul dalam jumlah banyak kemudian tersusun menjadi satu) (Daud, 2015). Tokoh muslin Indonesia banyak yang mendefinisikan ilmu salah satunya Endang Saefuddin Anshori dalam bukunya yang berjudul "Ilmu, Filsafat Dan Agama" menurutnya ilmu pengetahuan adalah usaha pemahaman manusia yang disusun dalam satu sistem mengenai kenyataan, struktur, bagian-bagian tentang hal-ihwal yang diselidiki (alam, manusia, dan agama) sejauh yang dapat dijangkau daya pemikiran yang dibantu penginderaan yang kebenarannya diuji secara empiris, riset dan eksprimen (Anshari, 1987).

Dalam tataran ilmu pengetahuan terdapat tiga jenis pengetahuan yaitu, 1) pengetahuan biasa, ialah hasil dari pengamatan rasa dan fakta sehari-hari dan disebut juga commonsense, 2) pengetahuan yang disusun secara sistematis dengan syarat dan metode yang ditetapkan, disebut juga dengan science, dan 3) pengetahuan yang dipaparkan dalam filsafat ilmu (Tamrin, 2019).

Penjelasan mengenai ilmu dan pengetahuan dengan berbagai aspeknya membawa kita kepada tahap pengujian dan pengevaluasian seluruh pengetahuan yang kita miliki secara sistematis. Dengan demikian kita dapat mengsignifikankan pengetahuan ke dalam tingkatantingkatannya sehingga sampai kepada Ilmu yang layak diterapkan ke dalam kehidupan bermasyarakat. Cara untuk mengevaluasi pengetahuan tersebut dibutuhkan metode dan sistem kerja hakikat ilmu yaitu ontologi, epistemologi dan aksiologi.

\section{Hakikat Ilmu: Ontologi, Epistemologi, dan Aksiologi}

Ilmu pengetahuan merupakan prestasi manusiawi yang pada dasarnya muncul dari semangat manusia terhadap hal baru. Dengan kata lain, pengetahuan lahir karena kebutuhan, manusia membutuhkan pengetahuan untuk menjawab berbagai macam tantangan mempertahankan eksistensinya (Wijaya C. N., 2006). Di dalam diri manusia terdapat bakat untuk mengembangkan akal dan pikiran yang akan menuntunnya mengarungi kehidupan.

Saat ini manusia cenderung tidak mengetahui hakikat ilmu secara mendalam. Sumber, metode yang sistematis serta kegunaan suatu pengetahuan cenderung diabaikan. Filsafat ilmu berperan sebagai penelusur dalam kegiatan pengembangan olah pikir manusia supaya terarah dalam mencari sebab musabab atas segala sesuatu. Potensi berfikir 
manusia perlu distrukturkan secara cermat supaya menuju pengetahuan yang akurat, benar dan bermanfat (Makhmudah, 2018). Dengan demikian eksistensi ilmu juga tidak dipandang sebagai sesuatu yang sudah final, ilmu perlu dikritisi serta dikaji untuk menguatkannya di posisi yang tepat dalam batas ruang lingkupnya, serta memenuhi pemahman yang rasional dan empiris mengenai kenyataan alam semesta (Sidharta, 2008).

Ilmu pengetahuan mengalami proses kompetensi, yaitu memiliki kemampuan meningkatkan keunggulan dan kekokohannya (from knowledge to science). Tahap yang sulit bagi suatu ilmu pengetahuan ialah mencapai "certitude level" ialah tidak ada lagi keraguan mengenai keberadaannya (Yist, 2015). Keadaan ini yaitu hubungan saling menguatkan antara subjek dan objek dengan intraksi yang benar. Dengan demikian hakikat ilmu dapat ditempuh dengan epistemologi yang tepat dan spesifik yaitu filsafat ilmu (Suriasumantri, Filsafat Ilmu Sebuah Pengantar Populer, 2009).

Pada dasarnya filsafat ilmu merupakan titik tolak mengenai objek apa yang ditelaah oleh ilmu (ontologi), bagaimana proses mendapatkan ilmu (epistemologi), dan bagaimana kegunaan ilmu tersebut (aksiologi) (Widyawati, 2013). Oleh karena itu, lingkup filsafat ilmu merupakan pengetahuan tentang hakikat, substansi dan paradigma dasar dari ilmu pengetahuan sehingga menghasilkan model, pola, yang ideal.

Pembahasan mengenai kata ontologi yaitu berasal dari bahasa Yunani "ontos" yang artinya "yang ada". Ontologi adalah bagian filsafat yang membahas mengenai objek kajian ilmu, meliputi perwujudan segala realitas yang ada dan mungkin ada, menjelajahi segala diemnsi yang mengitari manusia seperti pengetahuan alam semesta, moral dan sosial (Syafi'i, 2004). Berdasarkan objek kajian, dalam ilmu pengetahuan terbagi menjadi dua yaitu objek material dan objek formal. Objek material meliputi seluruh bahan yang dijadikan penyelidikan suatu ilmu, (empiris dan non empiris) sedangkan objek formal ialah penentuan titik tepat terhadap objek material atau memenuhi aspek empiris (Umar, 2018).

Kata epistemologi berasal dari bahasa Yunani terdiri dari dua kata yaitu logia yang artinya pengetahuan dan episteme artinya tentang pengetahuan. Dengan demikian epistemologi merupakan pengetahuan mengenai pengetahuan (Hamersma, 1992). Epistemologi menduduki bagian mempersoalkan sumber dan asal usul ilmu pengetahuan, serta berperan sebagai media penentuan cara atau metode untuk mencapai suatu ilmu, cara tersebut yaitu berupa kegiatan penelitian, percobaan, pengungkapan prinsip-prinsip ilmu serta menyatukan kekuatan struktur antara pikiran subjek dengan objek dalam menemukan ilmu pengetahuan yang benar (Bahrum S. M., 2013). Dalam hal ini bisa dipastikan bahwa epistemologi berkaitan erat dengan ontologi sebagai objek kajian ilmu. 
Penjelasan selanjutnya yaitu tentang aksiologi, kata asalnya axios yang artinya "bermanfaat" dan ditambah dengan kata logos yang artinya pengetahuan atau teori (Rosdakarya, 1995). Aksiologi ialah aspek ilmu pengetahuan yang menyelidiki nilai kegunaan ilmu pengetahuan sampai pada hakikat nilai ilmu dari seluruh sudut pandang. Dengan demikian nilai kegunaan ilmu tidak lepas dari kaidah-kaidah moral dan prosedur ilmiah yang tepat, kegunaan suatu ilmu bisa menimbulkan efek posistif dan negatif sehingga struktur penilaian harus memenuhi kaidah moral demi mencapai pengetahuan yang benar dan bermanfaat bagi kehidupan manusia.

\section{Rasionalisme dan Epirisme dalam Kerangka Ilmu Pengetahuan}

Penjelasan mengenai konsep dan struktur ilmu pengetahuan sudah menemukan kerangkanya yaitu, tiga unsur pokok di dalamnya terdapat objek, metode, dan nilai guna. Kemudian majulah pada tahapan penunjang epistemologi pengetahuan yang berkaitan dengan sumber atau cara yang ditempuh manusia untuk mendapatkan pengetahuan yang benar. Pada bagian ini erat kaitannya dengan paradigma atau cara pandang manusia terhadap penemuan ilmu pengetahuan.

Kegiatan manusia dalam memperoleh pengetahuan ialah mengalami pengamatan indera yang memberikan dua hal yaitu, ide (idea) dan kesan (impression). Ide adalah gambaran tentang persepsi yang dihasilkan dengan proses perenungan kembali atau merefleksikan sesuatu yang diterima dari pengalaman individu. Sedangkan kesan ialah apa yang diperoleh secara langsung dialami, kesan bersifat hidup dan langsung seperti mendengar, merasa dan melihat (Tafsir, Filsafat Umum: Akal Dan Hati Sejak Tales Sampai Capra, 2016). Dalam hal yang lebih spesifik terdapat enam sumber pengetahuan, yaitu pengalaman indera, nalar, wahyu, intuisi, otoritas dan keyakinan (Adib, 2011).

Secara epistemologis ada dua aliran filsafat yang mengkaji mengenai sumber munculnya ilmu pengetahuan dan menerapkan standar kebenaran yang ada di dalamnya. Kedua aliran tersebut ialah rasionalisme dan empirisme, paham ini terkait dengan pemerolehan ilmu yang dianggap benar dan keduanya memilki tokoh masing-masing dalam penyampaian argumen dasar untuk mempertahankan paham yang dianut.

Rasionalisme secara etimologis berasal dari bahasa Inggris rationalism dan kata ini berakar dari bahasa Latin yaitu ratio artinya "akal". Kemudian secara terminologis ialah aliran yang memiliki paham dan berpegang pada prinsip bahwa akal merupakan sumber utama ilmu pengetahuan yang benar. Akal menduduki posisi unggul dan bebas atau terlepas dari pengamatan inderawi, pengalaman hanya dipakai untuk mempertegas pengetahuan yang diperoleh akal, dengan demikian paham rasionalisme ialah berpusat pada akal (Machmud, 2011). 
Rasionalisme adalah aksioma dasar yang dipakai membangun sistem pemikiran yang diturunkan dari idea. Pikiran manusia memiliki kemampuan untuk "mengetahui" idea tersebut, namun manusia tidak menciptakannya dan tidak mempelajarinya lewat pengalaman. Idea tersebut sudah ada di sana (daya nalar) sebagai kenyataan dasar dan fikiran manusia. Kaum rasionalis berdalil, bahwa fikiran dapat memahami prinsip, maka prinsip itu harus "ada", artinya, prinsip harus benar dan nyata. Jika prinsip tidak "ada" orang tidak mungkin akan dapat menggambarkannya (Suriasumantri, Ilmu Dalam Perspektif , 2009).

Salah satu tokoh rasionalisme modern adalah Rene Descartes (15961650). Ia dijuluki sebagai bapak filsafat modern, Descartes berusaha memberi dasar metodis yang baru dalam filsafat, dengan metode tersebut Descartes memahaminya sebagai atauran-aturan yang dapat dipakai untuk menemukan kepastian dasar dan kebenaran yang kokoh (fundamentum certum et inconcussum veritatis). Metode itu disebutnya "le doute methodique" (metode kesangsian). Jadi, berfilsafat bagi Descartes berarti melontarkan persoalan metafisis untuk menemukan sebuah fundamen yang pasti (Hardiman, 2004).

Untuk menemukan titik kepastian itu Descartes mulai dengan sebuah kesangsian atas segala sesuatu. Dia mulai menyangsikan berbagai pandangan metafisis yang berlaku tentang dunia materi dan dunia nonmateri itu bukanlah tipuan belaka dari semacam iblis yang sangat licik, lalu apakah yang menjadi pegangan? Menurut Descartes, sekurang-kurangnya "aku yang menyangsikan" alam ini bukanlah hasil tipuan, semakin menyangsikan segala sesuatu, maka kesangsianlah yang membuktikan kepada diri kita bahwa alam ini nyata. Menyangsikan adalah berfikir, Descartes kemudian mengatakan Je Pense donc je suis atau cogito ergo sum (aku berfikir, maka aku ada) (Hardiman, 2004).

Keragu-raguan atau kesangsian Descartes hanyalah sebuah metode, bukanlah ragu-ragu skeptis atau ragu-ragu sungguhan. Keraguan untuk mencapai kepastian, hanya rasio yang dapat membawa orang kepada kebenaran. Mengenai apa dan siapa yang menjamin, idea itu benar adalah Tuhan itu sendiri, idea ialah pemberian Tuhan (Poedjawijatna, 1997). Sebab tak mungkin Tuhan memberi pedoman yang salah. Maka dari itu rasiolah alat pencari dan pengukur pengetahuan, itulah sebabnya maka aliran ini disebut Rasionalisme (Tafsir, Mengurai Ontologi, Epistemologi Dan Aksiologi Pengetahuan, 2004).

Kata empirisme secara etimologis dari bahasa Inggris empiricism dan experience, kata ini berakar dari bahasa Yunani empeiria dan experietia yang artinya "berpengalaman dalam". Kemudian secara terminologis pengertian empirisme ialah dokrin atau paham yang meyakini bahwa sumber seluruh pengetahuan harus berdasarkan pengalaman indera, ide hanya abstraksi yang dibentuk terhadap apa yang dialami, dan 
pengalaman inderawi ialah satu-satunya sumber pengetahuan (Bagus, 2002).

Dalam teori empiris terdapat dua aspek pokok yaitu, pertama ialah yang mengetahui (subjek) dan yang diketahui (objek) di antara keduanya terdapat alam nyata seperti fakta yang dapat diungkap. Kedua, pengujian kebenaran dari fakta didasarkan kepada pengalaman manusia, maka pernyataan ada atau tidak sesuatu haruslah memenuhi persyaratan pengujian pengematan publik (Suriasumantri, Ilmu Dalam Perspektif, 2009). Selanjutnya dari pemaparan ini kita dapat memahami bahwa ada enam ajaran empirisme yaitu: pertema, semua ide ialah abstraksi yang dibentuk oleh pengalaman, kedua pengelaman inderawi ialah satu-satunya sumber pengetahuan, ketiga semua yang diketahui bergantung pada data inderawi, keempat semua pengetahuan turun dan disimpulkan data inderawi kecuali kebenaran defisional metematika dan logika, kelima akal tidak dapat memberikan pengetahuan tanpa bantuan indera, dan keenam empirisme sebagai filsafat pengalaman (Puspitasari, 2012).

Pada zaman sekarang empirisme menjadi sikap dasar segala bentuk penelitian ilmiah. Pengetahuan harus didasarkan pada observasi empiris, dengan maksud untuk mengembalikan pengetahuan pada pengalaman dan berusaha membebaskan diri dari berbagai bentuk spekulasi spiritual dan cara berfikir tradisional. Dengan cara itu juga kaum empiris berusaha memisahkan filsafat dari teologi (Hardiman, 2004). Mereka berdalil bahwa tidak beralasan untuk mencari pengetahuan mutlak dan mencakup semua sisi, kaum empiris cukup puas dengan mengembangkan sebuah sistem pengetahuan yang mempunyai peluang yang besar untuk benar, meskipun pengetahuan mutlak tidak pernah dapat dijamin.

Aliran empirisme berkembang pesat pada masa renaisance yaiu sekitar abad ke-17 dan 18 di negara Inggris dan sekiatrnya. Aliran ini dirintis oleh tokoh filsuf Inggris yaitu Francis Bacon De Verulam (15611626) dan dilanjutkan oleh filsuf-filsuf lainya seperti John Locke, George Barkeley, Thomas Hobes dan David Hume (Sativa, 2011). Salah satu gagasan dari mereka yaitu David Hume (1711-1776) mengatakan pemikiran empirisnya tersimpul dalam satu ungkapan yang singkat yaitu "I never catch my self at anytime without a perception" artinya (saya selalu memiliki persepsi pada setiap yang saya alami), dari ungkapan ini David Hume menyampaikan bahwa seluruh pengalaman dan pemikiran tersusun dari rangkaian kesan (impression) (Machmud, 2011).

Pada dasarnya aliran ini muncul karena ada anggapan bahwa kaum rasionalis tidak cukup mampu menstrukturkan kerangka pengetahuan berasal dari akal saja dan mereka berpendapat akal itu bersifat polos dan ia akan terisi apabila diisi dengan bantuan indera sebagai alat untuk mendapatkan pengalaman (Juhari, 2013). Namun aliran ini tetap memiliki kelemahan seperti pada pengalaman inderawi yang sifatnya terbatas dan 
objek bisa saja menipu seperti ilusi (Wilardjo, 2009). Pada dasarnya fungsi dari kedua aliran tersebut tidak lepas hanya sebagai alat untuk mempertanggungjawabkan suatu ilmu dan pengetahuan yang diajukan oleh seorang ilmuan kepada khalayak umum baik berupa teori baru, hasil rekonstruksi, gagasan-gagasan, dan ide sebagai hasil pikiran (Mudzakir, 2016). Dengan demikian ilmu dan pengetahuan bisa dicapai secara benar menurut akal dan dapat dibuktikan dengan pengamatan.

\section{Kesimpulan}

Ilmu pengetahuan adalah bukti berfungsinya akal dan fikiran manusia. Kemampuan memiliki pengetahuan adalah naluri paling besar sebagai kelebihan dan keunggulan manusia, hal ini ditunjukkan dengan ciri khusus yaitu manusia memiliki curiosity (rasa ingin tahu) yang tinggi yang mengakibatkan manusia sering bertanya dan mencari tahu tentang sesuatu. Pengetahuan dihasilkan dari rasa ingin tahu dan sejalan dengan prinsip pengamatan maka ilmu dan pengetahuan dapat dicapai dengan benar sebagai pertanggungjawaban eksistensi manusia di muka bumi. Ilmu dan pengetahuan memiliki perbedaan yang signifikan walaupun keduanya tampak sama dan selalu berdampingan. Ilmu (science) memiliki struktur dan sistematis dalam mencapai suatu kesimpulan sedangkan pengetahuan (knowledge) meliputi semua hal yang diketahui manusia, baik yang terstruktur maupun tidak terstruktur. Pengetahuan bisa berupa fakta, berita, mitos dan hal yang bersifat dogma. Pengetahuan tidak harus memenuhi syarat sistematis hanya saja pengetahuan dapat naik derajat menjadi ilmu dengan cara memenuhi aspek ontologi, epistemologi dan aksiologi dalam kerangka ilmu pengetahuan. Ketiga aspek ini membongkar pengetahuan sehingga menjadi akurat dan benar serta dapat dipertahankan keabsahannya. Ilmu pengetahuan yang dimiliki manusia secara epistemologis bersumber pada dua aliran pemahaman, yaitu rasionalisme dan empirisme. Rasionalisme ialah paham yang meyakini bahwa sumber utama pengetahuan manusia terletak pada akal atau disebut dengan idea, sedangkan empirisme ialah paham yang meyakini bahwa satu-satunya sumber pengetahuan yang akurat adalah dari pengalaman inderawi. Keduanya memiliki argumen yang kuat dan melahirkan tokohtokoh yang terkenal dalam bidang keilmuan, sehingga dua paham ini seolah beradu dalam panggung kompetisi yang panas, namun pada dasarnya keduanya hanyalah alat untuk mengokohkan suatu ilmu pengetahuan supaya diterima oleh nalar dan indera. Diharapkan penelitian ini memiliki manfaat bagi para pelajar untuk menstrukturkan pengetahuan yang dimilki supaya menjadi ilmu yang benar. Keterbatasan penelitian ini ialah tidak membahas secara mendalam mengenai jenis aliran yang menanggapi rasionalisme dan empirisme, hanya memaparkan struktur awal saja. Penelitian ini direkomendasikan untuk bahan rujukan bagi 
lembaga pendidikan yang berkaitan dengan kajian filsafat, agama, dan pemikiran.

\section{Referensi}

Adib, M. (2011). Filsafat Imu Ontologi, Epistemologi, Aksiologi Dan

Logika Ilmu Pengetahuan . Yogyakarta : Pustaka Pelajar.

Al-Faruq, I. R. (1984). Islam dan Kebudayaan . Bandung : Mizan.

Anshari, E. S. (1987). Ilmu, Filsafat Dan Agama. Surabaya: PT Bina Ilmu.

Azmi, M. N. (2018). Manusia, Akal Dan Kebahagiaan. Jurnal Ilmiah Al-

Qalam, 124.

Bagus, L. (2002). Kamus Filsafat . Jakarta: PT. Gramedia Pustaka Utama.

Bahktiar, A. (2004). Filsafat Ilmu . Jakarta : Amtsal Bahktiar.

Bahrum, S. M. (2013). Ontologi, Epistemologi Dan Aksiologi . Jurnal

Sulesana, 36.

Baktiar, A. (2012). Filsafat Ilmu . Jakarta: Rajawali Pers.

Banasuru, A. (2013). Filsafat Dan Filsafat Ilmu Ke Tanggung Jawab.

Bandung: Alfabeta.

Bayu Purbo Asmoro, F. D. (2019). Peningkatan Rasa Ingin Tahu Ilmu

Pengetahuan Alam Melalui Model Contextual Teaching And

Learning Pada Siswa Kelas VA Sekolah Dasar Negeri Karangroto 02 .

Jurnal Abdau , 118.

Dafrita, I. E. (2015). Ilmu Dan Hakekat Ilmu Pengetahuan Dalam Nilai Agama. Jurnal Al-Hikmah , 159.

Darmalaksana, W. (2020). Cara Membuat Proposal Penelitian. Bandung:

Fakultas Ushuluddin UIN Sunan Gunung Djati Bandung.

Darmalaksana, W. (2020). Formula Penelitian Pengalaman Kelas Menulis.

Kelas Menulis UIN Sunan Gunung Djati Bandung, 1-8.

Darmalaksana, W. (2020). Metode Penelitian Kualitatif Studi Pustaka dan

Studi Lapangan. Pre-Print Digital Library UIN Sunan Gunung Djati

Bandung.

Daud, I. R. (2015). Ilmu Pengetahuan Dari John Locke Ke Al-Attas. Jurnal Pencerahan, 12-22.

Gallagher, K. T. (2010). Epistemologi Filsafat Pengetahuan . Yogyakarta :

Kanisius.

Hamersma, H. (1992). Pintu Masuk ke Dunia Filsafat . Yogyakarta :

Kanisius.

Hardiman, F. B. (2004). Filsafat Modern . Jakarta : Gramedia Pustaka

Utama.

Indrioko, E. (2020). Sumber-Sumber Ilmu Pengetahuan Dalam Manajemen

Pendidikan Islam . Jurnal Hijri , 20-36.

Juhari. (2013). Muatan Sosiologi Dalam Pemikiran Filsafat John Locke . 
Jurnal Al-Bayan , 8.

Karim, A. (2014). Sejarah Perkembangan Ilmu Pengetahuan . Jurnal Fikrah , 273.

Khotimah, K. (2014). Paradigma Dan Konsep Ilmu Pengetahuan Dalam Alquran. Jurnal Episteme , 68.

Kirom, S. (2011). Filsafat Ilmu Dan Arah Pengembangan Pancasila:

Relevansinya Dalam Mengatasi Persoalan Kebangsaan. Jurnal

Filsafat , 100 .

Komariah. (2017). Struktur Ilmu Pengetahuan . Jurnal Genologi PAI , 6984.

Lubis, A. Y. (2011). Pengantar Filsafat Pengetahuan . Depok: Penerbit Koekoesan.

Machmud, T. (2011). Rasionalisme Dan Empirisme, Kontribusi Dan

Dampaknya Pada Perkembangan Filsafat Matematika. Jurnal Inovasi, 115.

Makbul, M. (2020). Filsafat Ilmu: (Filsafat Ilmu, Klasifikasi Ilmu, Ciri-Ciri Ilmu, Dan Sistem Kerja ILmu. Osf.io, 1.

Makhmudah, S. (2018). Hakikat Ilmu Pengetahuan dalam Perspektif

Modern dan Islam. Al-Murabbi, 203.

Marpaung, I. M. (2011). Konsep Ilmu Dalam Islam . Jurnal At-Ta'dib, 260. Mudzakir. (2016). Pran Epistemologi Ilmu Pengetahuan Dalam

Membangun Peradaban . Jurnal Kalimah , 280.

Munir, M. I. (2004). Tinjauan Terhadap Metode Empirisme Dan

Rasionalisme . Jurnal Filsafat, 234.

Poedjawijatna. (1997). Pembimbing ke Arah Filsafat . Jakarta: PT Rineka Cipta.

Puspitasari, R. (2012). Kontribusi Empirisme Terhadap Pendidikan Ilmu Pengetahuan Sosial. Jurnal Edueksos, 29.

Rosdakarya, T. P. (1995). Kamus Filsafat. Bandung : Remaja Rosdakarya. Rusmini. (2014). Dasar Dan Jenis Ilmu Pengetahuan . Jurnal Edu-Bio, 79. Sativa. (2011). Empirisme, Sebuah Pendekatan Penelitian Arsitektural. Jurnal Inersia , 115.

Sidharta, A. (2008). Apakah Filsafat dan Filsafat Ilmu Itu ? Bandung :

Pustaka Sutra.

Suriasumantri, J. S. (2009). Filsafat Ilmu Sebuah Pengantar Populer .

Jakarta : Pustaka Sinar Harapan.

Suriasumantri, J. S. (2009). Ilmu Dalam Perspektif . Jakarta : Yayasan Obor Indonesia.

Syafi'i, I. K. (2004). Pengantar Filsafat . Bandung: Refika Aditama.

Tafsir, A. (2004). Mengurai Ontologi, Epistemologi Dan Aksiologi

Pengetahuan. Bandung: PT Remaja Posdakarya.

Tafsir, A. (2016). Filsafat Umum: Akal Dan Hati Sejak Tales Sampai Capra.

Bandung : Rosdakarya. 
Tamrin, A. (2019). Relasi Ilmu, Filsafat dan Agama Dalam Dimensi Filsafat Ilmu. Jurnal Salam, 72.

Umar. (2018). Filsafat Ilmu: Suatu Tinjauan Pengertian Dan Objek Dalam Filsafat Pengetahuan. Jurnal El-Muhbib, 168.

Wahana, P. (2016). Filsafat Ilmu Pengetahuan . Yogyakarta : Pustaka Diamond.

Widyawati, S. (2013). Filsafat Ilmu Sebagai Landasan Pengembangan Ilmu Pendidikan. Jurnal Gelar, 94.

Wijaya, C. N. (2006). Ilmu Dan Agama Dalam Perspektif Filsafat Ilmu. Jurnal Filsafat, 175.

Wijaya, T. S. (2017). Teologi Rasional Ijtihadi Dan Dogmatis Taqlidi Penalaran Filsafat Kalam . Jurnal Substansia, 1.

Wilardjo, S. B. (2009). Aliran-Aliran Dalam Filsafat Ilmu Berkait Dengan Ekonomo. Jurnal Unimus, 6.

Wilujeng, S. R. (2014). Ilmu Dalam Perspektif Filsafat (Suatu Upaya Mengembalikan Ilmu Pada Hakikatnya). Jurnal Humanika , 93.

Yazdi, M. T. (1999). Philoshophical Intructions; AnIntroduction do Comtemporary Islamic Philoshophy. Institute Of Global Cultural Studie University Of Binghamton.

Yist, F. V. (2015). Eksistensi Ilmu Pemerintahan . Jurnal Cosmogov, 02. 